\title{
RIGHT TO PROPERTY: FROM MAGNA CARTA TO THE EUROPEAN CONVENTION ON HUMAN RIGHTS
}

DOI: $10.1515 /$ seeur-2015-0018

\begin{abstract}
Property rights are integral part of the freedom and prosperity of every person, although their centrality has often been misprized and their provenance was doubted. Yet, traces of their origin can be found in Magna Carta, signed by the King of England in 1215. It was a turning point in human rights. Namely, it enumerates what later came to be thought of as human rights. Among them was also the right of all free citizens to own and inherit property. The European Convention on Human Rights was heavily influenced by British legal traditions, including Magna Carta. Among other rights, it also guaranties the right to property as a human right. Moreover, the protection of property rights has been extended to intellectual property rights as well. Namely, the European Court of Human Rights has provided protection of intellectual property rights through the adoption of decisions that interpret the right to property, in relation to intellectual property protection claims. It has extended the human rights protection of property to the mere application for registration of the trade mark. This paper has placed its focus on the development and treatment of the right to property starting from Magna Carta to the European Convention on Human Rights, as modern version of Magna Carta. In this sense, the jurisprudence of the European Court of Human Rights and its role and approach in the protection of the right to property will be examined as well.
\end{abstract}

\section{INTRODUCTION}

The English word "property" is derived from the Latin word proprius, which means "own". It differs from the word communis, which means "common", and the word alienus, which means "another's". According to this etymology, property is associated with some type of individuality. Namely, it means that property belongs to someone in particular, rather than to a group or the public. This postulate is the basis of the concept of property of the Western political and legal traditions (O'Neill, 2013: 309)

The treatment of property reveals much about the society's conception of justice and good government. Modern political theory has been concerned with private property and its relationship to work and the distribution of valued resources for a long time. These topics inevitably involve arguments about human nature and the human good. Today, in a system of market exchange, there is almost no doubt that robust protection of private property best guarantees productivity and secures prosperity. This approach to property is the appropriate one, because the limits and duties associated with it coordinate human interaction in a way that allows people to specialize, trade and invest efficiently (Schmidtz, 1994: 4262) 
The role of private property as also being the guarantor of liberty is recognized even by the most loyal contemporary defenders of the economic utility of private property, against even the logic of economic efficiency. This is due to the fact that private property protects individuals from exploitation and from the vagaries of market. Consequently, it means that property's connection to liberty, choice, and consent means has figured prominently in thinking about constitutionalism for quite a time, especially since the writings of John Locke in the late seventeenth century. Namely, according to Locke, "property is the protection of consent...not merely or chiefly what supplies men's needs; it is what keeps men free". In fact, although the distribution of resources has always been an issue, for the last several hundred years at least, the Western thought considers that the pre-political and natural basis of property is in the human individual and the human desire for liberty (O’Neill, 2013: 309-310).

This paper has placed its focus on the development and treatment of the right to property starting from Magna Carta to the European Convention of Human Rights, which was significantly influenced by British traditions, including the Magna Carta. It also conducts an analysis of the jurisprudence of the European Court of Human Rights as regards the protection of the right to property, which has been extended to intellectual property rights as well. In this sense, the paper also examines the development and treatment of intellectual property rights in the jurisprudence of the European Court of Human Rights, thus answering the question of what should be the role and approach of the Court to the protection of intellectual property rights.

\section{GENESIS OF THE RIGHT TO PROPERTY: AN OVERVIEW 800 YEARS LATER}

This year is the $800^{\text {th }}$ anniversary of the Magna Carta. It is the Great Charter which was a turning point in human rights and has led to the modern idea of human rights. It enumerates what later came to be thought of as human rights. Among them was also the right of all free citizens to own and inherit property. Namely, the Great Charter of 1215 established the clear principle that a person's property could not be seized by the King. The simple proposition provided the foundation for property rights protection (Wilson, 2015: 29).

In 1214, the English barons revolted against King John as they were burdened by his violations of feudal law and custom. He violated both the substantive and procedural rights of his constituents as established by the common law, custom and agreement. He imposed new rules and penalties at his will and punished the charged ones without fair process. The conflict was terminated by signing the document Magna Carta on June 15, 1215. Namely, the king executed a formal document containing 63 chapters that the barons submitted to him. The document was originally known as the Charter of Liberties, or the Articles of the Barons, and subsequently called the Great Charter or the Magna Carta. By signing the Magna Carta, amongst other things, the king agreed to return the properties he had seized and to suspend the fines he had imposed by violation of existing rules and customs. He also agreed that a free man will be punished only for violating existing rules and in proportion to the gravity of the violation committed and that a free man would not otherwise be deprived of his liberties and properties (Siegan, 2001: 6).

Namely, the most important commitments of the king were contained in Chapter 39, which foresees the following: "No freeman shall be arrested, or detained in prison, or deprived of his freehold, or in any way molested; and we will not send forth against him, nor set against him, unless by the lawful judgment of his pears or by the law of the land". In this chapter, King John agreed that in the future he would not deprive free man of their lives, liberties, or properties unless it was required by existing and proper laws and, then, only pursuant to fair and proper procedures. In this manner, he renounced his authority to execute arbitrary laws or rules destroying or damaging freemen, which was his previous practice (Siegan, 2001: 7). 
The Magna Carta was repealed by King John only a few months after he had accepted. However, it was replaced by others after King John's death executed in the reign of his son, Henry III. The Magna Carta issued in 1225 by Henry III is considered to be the definitive version of the document that guaranteed the liberties of Englishmen (Siegan, 2001: 10).

The principle that no Englishman could have his life, liberty, or property taken but by the "law of the land" was considered fundamental to English identity. The significance of this principle was expressed in documents from Magna Carta in 1215 to the English Bill of Rights in 1689. It was also expressed in the decisions of Sir Edward Coke (1552-1634) and in his Institutes of the Laws of England (1600-1615). According to Coke, common law courts and doctrines are on the side of the individual against both King and Parliament, emphasizing that in English jurisprudence "these protections were outside, above, and beyond the reach of the positive law" (O'Neill, 2013: 310)

The accentuation of the importance of property in English law does not mean that property rights were absolute or beyond regulation. Namely, although William Blackstone's Commentaries on the Law of England (1765-69) define property in absolutist terms, as "that sole and despotic dominion which one man claims and exercises over the external things of the world, in total exclusion of the right of any other individual in the universe", the main purpose of the Commentaries is to explain how detailed the common law regulated the use and conveyance of property (O'Neill, 2013: 311).

Both Coke and Blackstone interpreted Magna Carta as prohibiting the adoption of arbitrary laws and guaranteeing that no freeman shall be deprived of his life, liberty, or property, unless it is done in accordance with the law of the land. Coke referred to this principle as due process of law, which required a fair and proper judicial trial and compliance with other laws of the land. Also, both commentators agreed that laws must not be retroactive and must serve a public interest. Coke, while serving as a judge, contributed to various important rulings, among which is the ruling that regulatory laws must advance the purpose for which the government had adopted them and that no person should be a judge in his own cause as well as the ruling that monopolies were illegitimate because they deprived people of their freedom to engage in economic activity. He also supported economic rights, because every person possesses the liberty to practice the trade, occupation, or vocation of his choice. (Siegan, 2001: 12-46).

Blackstone was a strong defender of individual rights as well. According to him "every wanton and causeless restraint of the will of the subject, whether produced by a monarch, nobility, or a popular assembly is a degree of tyranny." Laws that "regulate and constrain our conduct in matters of mere indifference, without any good end in view, are destructive of liberty." Property rights were crucial in Blackstone's vision of individual liberty. The most important safeguards for property owners, according to Blackstone, are awarding indemnification to a nonconsenting owner whose property is taken and protection of the property owner against physical invasion of his property by the laws of trespass and nuisance (Siegan, 2001: 29-46).

The revolutionary ideas on property and civil and political rights were greatly developed by the English philosopher John Locke (1632 - 1704). In his Two Treaties of Government (1689) he refers to "lives, liberties and estates" as the "property" of individuals. John Lock put property rights within the human rights discussion. In his Second Treatise, Lock stated that: "Every man has a property in his own person...the labor of his body, and the work of his hands, we may say, is properly his". Locke understood that property is the moral and just reward of individual activity. Consequently, denying property is similar to denying someone the reward for their labor. According to Lock, property ownership derives from one's labor, but he also argued that those who do not own property and only have their labor to sell should not be given the same political power as those who owned property. They should have civil and political rights in proportion to the property they owned. Furthermore, he considered the right to property and the right to life to be inalienable rights, while it is the responsibility of the State to guarantee these rights for individuals. Locke believed that the protection of natural rights, 
such as the right to property, along with the separation of powers and other check and balances, would contribute to reduction of the political abuses by the state (Wilson, 2015:29)

Locke's arguments on property and the separation of power greatly influenced the American Revolution (1765-1783) and the French Revolution (1789-1799). The entitlement to civil and political rights, such as the right to vote, was tied to the question of property in both revolutions. American Revolutionaries opposed universal suffrage only for those who owned a certain property. While it was initially suggested to establish the right to vote for all men, eventually the right to vote was extended to white men who owned a specified amount of real estate and personal property. French Revolutionaries recognized property rights in Article 17 of the Declaration of the Rights of Man and of the Citizen (1789). It stated that no one "may be deprived of property rights unless a legally established public necessity required it and upon condition of a just and previous indemnity." Furthermore, in Article 3 and 6 it was foreseen that "all citizens have the right to contribute personally or through their representatives" in the political system, and that "all citizens being equal before the law, are equally admissible to all public offices, positions and employment according to their capacity, and without other distinction than that of virtues and talents". However, in practice the French revolutionaries did not extended civil and political rights to all, although the property qualification required for such rights was lower than that established by the American revolutionaries (O’Neill, 2013: 3012-320)

It may be argued that property rights are the foundation of all human rights. Namely, the basis of natural rights theory is that people own their own bodies and should be free to exercise their capabilities to pursue their lives, opportunities and enterprise unless they do harm to others. Yet, despite property rights providing the foundations for human rights, the subject has always been controversial in their modern development, particularly through international treaties (Wilson, 2015: 30).

The place of private property rights in the human rights treaties has always been controversial. Namely, there is a general consensus that property is a fundamental right, but finding a consensus as regards the notion of a fundamental right to property has never been possible. This situation is a result of two main reasons. First, it is difficult to include the right to property as part of the human rights array in a situation where human rights are defined as rights that are inherent to human beings based on their humanity. Second, the debates regarding the place of property rights in society are still ongoing. There are various perspectives around the world about the place of property rights in legal system (Cullet, 2007: 405).

However, there are arguments both in favor of and against the protection of property as a human right. The positive arguments are that property rights are considered as means to foster security, to protect the individual's autonomy, to provide a basis for participation in a democratic society, and to contribute to the protection of other human rights, such as the right to privacy. The negative arguments are that private property rights may constitute a source of inequality and accept existing ownership patterns without taking in account their legitimacy. From a different perspective, it may be asked whether all types of property can or should fall within the scope of human rights protection and whether different types of property should be protected differently (Cullet, 2007: 406).

Property rights were a clear battleground in the development of the Universal Declaration of Human Rights (1948), which was a wide spread reaction to the Nazi genocide and the brutality of World War II (Chapman, 1999: 132)

An analysis of drafts of the Declaration found that "a majority of the drafts refer to the right to property, either in positive language or by prohibiting unlawful expropriation". However, the views on how broad property rights should be respected were a battleground. With support from the Soviet Union and socialist countries, countries such as Panama stressed that the protection for private property should be limited to "personal property" (Wilson, 2015: 30).

Yet, the West won a temporary victory. General protection of property was foreseen in Article 17 of the Universal Declaration of Human Rights, which was described as the "international Magna Carta" 
for mankind by Eleanor Roosevelt, one of its architects. It demonstrated the British origins of its ideological framework. However, the established recognition of property was undone during the development of the International Covenant on Civil and Political Rights. Namely, the right to property is one of the few rights that were included in the UDHR, but it was not included in the ICCPR (Wilson, 2015: 31).

The right to property had also been a subject of long debate in the process of drafting the European Convention on Human Rights (1950). Eventually, the right to property was not included in the primary text of the Convention, but it was added in the First Protocol to the Convention, which was opened for signature in 1952 and entered into force in 1954. (Bates, 2010: 100)

The main intention behind the adoption of the ECHR was to provide an early warning mechanism against totalitarian tendencies in Europe. Althaugh the democratic instititions in the member states of the Council of Europe, at the time when the Convention was drawn up, were well-developed and stable, Hitler's rise to power had shown how democracy and freedom could be easily threatened and eliminated. The idea of the member states was to create a catalogue of fundamental democratic rights and an international supervisory mechanism, which would serve as a detector of totalitarian tendencies in any of the member states, alerting the other states and enabling them to react in a timely fashion. The experts who developed a draft of the Convention on behalf of the Consultative Assembly (now: Parliamentary Assembly) of the Council of Europe considered that the right to property is one of those rights, because of its importance for personal liberty (Bates, 2010: 100)

However, after the draft had been submitted to the Committee of Ministers, the Committee created its own group of experts, who removed the right to property from the catalogue of rights to be secured by the member state, without any discussion of the issue with the Consultative Assembly. This was done partly due to concerns by the then socialist British government that it might interfere with the government's agenda of socializing property and strengthen obligations entailed by ownership (Bates, 2010: 100)

The Parlamentary Assemmbly protested against the decision of not including the right to property in the Convention. The protest urged the Committee of Ministers to form a group of experts to draft a Protocol to the European Convention on Human Rights, which would provide for the protection of property. The result was Protocol 1 to the ECHR, which entered into force in 1954 (Bates, 2010: 100)

\section{EUROPEAN CONVENTION ON HUMAN RIGHTS: MAGNA CARTA IN THE MODERN AGE?}

Magna Carta was sealed at Runnymede in June 1215 by King John, while the European Convention on Human Rights was signed in Rome, almost 750 years later, in November 1950 by ministers from fifteen countries, including Britain. Yet, the comparison between the two documents shows that the European Convention on Human Rights can be viewed as a modern equivalent of Magna Carta.

Of course, each document was agreed and signed under very different circumstances, separated by seven and a half centuries. Magna Carta was signed as a result of years of dispute between King John and a group of influential barons, and it was inspired by the coronation oath sworn by Henry 1 more than a century earlier, while the European Convention on Human Rights is an international agreement, with a purpose to establish common standards of human rights after the horrors of the Second World War and the Holocaust (Rathbone, 2014: 1)

However, it is indisputable that the Convention was deeply influenced by British legal traditions, including the Magna Carta, especially having in mind the fact that British lawyers, notably David Maxwell Fyfe, Conservative MP, took a leading role in the drafting of the Convention. There were also other historic sources of inspiration, such as the French revolutionary Declaration of the Rights of Man 
(1789), the US Bill of Rights (1791), and the Universal Declaration of Human Rights (1948). Yet, the fact that in March 1951 Britain was the first country to ratify the ECHR suggests that it is much consistent with the British legal traditions (Rathbone, 2014: 1)

Large part of the content of Magna Carta has little apparent relevance today, considering that it is mainly preoccupied with the complexities of relations between monarch and their subjects in a feudal society. Yet there are several parts which are very similar with certain articles of the ECHR.

Article 4 of the ECHR, which guarantees prohibition of slavery and forced labor, declares that, "No one shall be required to perform forced or compulsory labour", while Article 23 of Magna Carta (all article numbers refer to the original 1215 version of Magna Carta) stated that, "No village or individual shall be compelled to make bridges at river banks." Although Article 23 of Magna Carta is narrower and more specific in its scope, it shares the ECHR's view to prohibit the arbitrary imposition of forced labour by an autocratic government.

Article 6 of the ECHR, which guarantees the right to a fair trial, requires that any citizen accused of criminal charges, "is entitled to a fair and public hearing within a reasonable time by an independent and impartial tribunal established by law." It is clear that this fundamental human right owes much to Article 39 of Magna Carta, which stated that, "No freemen shall be taken or imprisoned ..., except by the lawful judgment of his peers or by the law of the land."

Article 21 of the ECHR is concerned with the quality of judges, requiring them to "be of high moral character" and to "possess the qualifications required for appointment to high judicial office". King John in Article 45 of Magna Carta has obliged to, "appoint as justices, constables, sheriffs, or bailiffs only such as know the law of the realm and mean to observe it well."

Article 1 of Protocol No. To the ECHR, which protects the right to property, declares that, "No one shall be deprived of his possessions except in the public interest and subject to the conditions provided for by law..." It is clear that this fundamental human right as well owes much to Article 39 of Magna Carta, which stated that, "No freemen shall... be disseised of his freehold, except by the lawful judgment of his peers or by the law of the land."

One substantial difference between Magna Carta and the ECHR is that Magna Carta was a purely English invention, while the Convention is an international agreement. However, both Magna Carta and the ECHR were created for the protection of citizens, not for the convenience of governments (Rathbone, 2014: 4-5)

\section{RIGHT TO PROPERTY IN THE JURISPRUDENCE OF THE EUROPEAN COURT OF HUMAN RIGHTS}

Article 1 of Protocol No. 1 to the European Convention of Human Rights guarantees the right to property. It provides the protection of "the peaceful enjoyment of possessions" for "every natural or legal person". The protection of the right to property is one of the more controversial provisions in the European human rights system. Namely, the right is not placed in the primary text of the Convention, but, as mentioned earlier, it is foreseen within Article 1 of its Protocol 1. The placement of the property provision and the absence of the word "rights" implicate a disagreement of the European governments regarding the inclusion of the property rights provision in the Convention, as well as a disagreement regarding the scope of the right and the level of protection it provides. (Helfer, 2008: 7-8)

The authors of the ECHR confirm that democratic governments should be allowed to have freedom in terms of adoption and modification of the economic and social policies, which encompass the private property without, in every case, providing compensation for the adversely affected owners. On the other hand, the authors of the Convention also point out that the rule of law, in general, particularly the 
stability and predictability of the property rights, could be seriously undermined if governments could arbitrarily deprive the owners of their property. In an attempt to reconcile these opposite perspectives, the European Court of Human Rights has created a very complex jurisprudence as a result of the interpretation of the right to property. (Helfer, 2008: 8)

The Court held that there are three distinct rules, which comprise Article 1 of Protocol No. 1. Namely, the Court conducted this analysis for the first time in the case of Sporrong and Lonnroth v. Sweden. The judgment issued as regards this case is one of the most important judgments of the Court in relation to this Article of the Convention. The rules, which were defined in this judgment, are the following: "... The first rule, which is of a general nature, enounces the principle of peaceful enjoyment of property; it is set out in the first sentence of the first paragraph. The second rule covers deprivation of possessions and subjects it to certain conditions; it appears in the second sentence of the same paragraph. The third rule recognises that the States are entitled, amongst other things, to control the use of property in accordance with the general interest, by enforcing such laws as they deem necessary for the purpose; it is contained in the second paragraph." (Grgic, Mataga, Longar and Vilfan, 2007: 10).

When evaluating whether there has been a violation of Article 1 of Protocol No. 1, the first step to be undertaken by the Court is to examine whether the property right (a possession) in question falls within the ambit of that provision. The second step is to determine whether there has been interference with that possession. The last step is to determine the nature of that interference (i.e. which of the three rules applies). However, it should be taken in consideration that the three rules are not unconnected. In this sense, the second and the third rule, which are concerned with particular instances of interference with the right to peaceful enjoyment of property, should be interpreted in the light of the general principles articulated in the first rule (Grgic, Mataga, Longar and Vilfan, 2007: 10).

Article 1 of Protocol 1 to the Convention guarantees the right to property in substance (Marcks v. Belgium). Intangible property is also encompassed within this protection (Van Marle and Others v. the Netherlands). The concept of property, which is independent in its scope, is interpreted extensively and encompasses all property constituting assets (Wiggins v. the United Kingdom). Any economic interest, which represents some type of an asset, can be considered as possession for the purposes of Protocol 1 (Tre Traktorer AB v. Sweden). In this sense, all the economically important types of tangible and intangible property, including land, chattels, licenses, contractual rights, corporative securities and, as described further, intellectual property, can be enumerated as an economic interest in the context of Article 1 of Protocol 1 to the Convention (Renucci, 2005: 51-52; Спировски, 2007: 268-292; Coban, 2004: 124-125).

The temporal scope of Article 1 of Protocol 1 extends to current and future proprietary interests. According to the findings of the Court, the term "possessions" means either existing possessions or assets, including claims, in respect of which the applicant has at least a legitimate expectation to obtain effective enjoyment of a property right (Kopecky v. Slovakia). The Court has extended the latter to enforceable debts, lease renewal options, final court judgments and acquired rights to social security and pension benefits. Furthermore, the Court held that only the mere hope of recognition of a property right which cannot be exercised effectively is not protected, nor is the conditional claim which lapses due to non-fulfillment of the condition (Gratzinger v. Czech Republic) (Helfer, 2008: 8-9).

The right to peaceful enjoyment of possessions, as mentioned earlier, is of a general nature and any limitations in that regard should be interpreted in that sense, in order to establish whether it is a loss of peaceful enjoyment of possessions or merely restrictions (James and Others v. the United Kingdom). In any case, the governments should be cautious when undertaking measures, which have affect over the economic interests of private individuals. A certain level of interference is allowed, given that the fair balance between public interest requirements and the need for protection of the fundamental rights of others is respected (Forrer-Niedenthal v. Germany) (Renucci, 2005: 52-53; Спировски, 2007: 268292). 
The deprivation of possessions is defined as complete and final dispossession, which could arise, for example, from nationalization, expropriation and confiscation. However, according to the finding of the Court in the case Sporrong and Lonnroth v. Sweden, precedence will not be given to the legal classification, but to the real effect of the undertaken activity, while de facto expropriation will be considered on an equal level with the formal expropriation (Renucci, 2005: 53; Спировски, 2007: 268292).

In terms of the conditions for deprivation of possessions, Article 1 of Protocol 1 foresees three conditions: compliance with the conditions foreseen in domestic law, observance of the general principles of international law and existence of public interest. Moreover, the Court will determine whether there is a reasonable proportionality between the means used and the aim pursued (Motais de Narbonne v. France). The right to compensation of the persons deprived of their possessions is a condition established by the Court, whereby the compensation should be prompt and effective (Akkus v. Turkey and Zubani v. Italy). Starting from the judgement in the case of Sporrong and Lonnorth v. Sweden, issued in 1982, the payment of compensation for deprivation of possessions is a general rule, with reservation in exceptional circumstances. However, unlawful deprivation of possessions cannot be remedied by granting compensation (Chater v. the United Kingdom). Furthermore, the second paragraph of Article 1 of Protocol 1 to the Convention, provides peaceful enjoyment of property does not prevent states to adopt laws in order to limit the right to property, due to reasons necessary to control the use of property in accordance with the general interest or to secure the payment of taxes or other contributions or penalties (Rancic, 2005: 53-54; Спировски, 2007: 268-292).

When evaluating the previously mentioned factors, a significant discretion is allowed to governments by the European court of Human Rights, in order to regulate private property in the public interest. Having in consideration that the states often establish control over property when implementing wider social and economic policies, the national authorities, which in fact have direct knowledge of their society and its needs, are in a better position than the international judge to decide whether a need for regulation exists, in order to achieve such policies (Draon v. France). Due to that, the Court gives a significant deference to the assessment of the legislator as regards what is considered as public interest, unless the assessment is evidently without reasonable foundation (Draon v. France). The Court also emphasizes the wide margin of appreciation enjoyed by the states as regards choosing the enforcement means, as well as determining whether the consequences of the enforcement are justified for the benefit of the general interest, in order to achieve the purpose of the law in question (Helfer, 2008: 10-11).

However, the foregoing does not mean that the Court allows the European governments to act arbitrarily. To the contrary, the Court has decisively refused to give up its power of review and has retained the final authority to determine whether the necessary balance is respected in a manner which is in accordance with the right to property (Helfer, 2008: 11).

\section{INTELLECTUAL PROPERTY IN THE JURISPRUDENCE OF THE EUROPEAN COURT OF HUMAN RIGHTS}

At first glance, it is not very clear what an international human rights court and the human rights treaty it interprets has to do with intellectual property. The answer of this issue is the right to property, which is protected by Article 1 of Protocol 1 to the European Convention of Human Rights.

As mentioned earlier, the protection of "the peaceful enjoyment of . . possessions" in Article 1 of Protocol 1 has been considered among the weakest rights in the Convention system for a long time, affording governments broad discretion to regulate private property in the public interest. Partly for this reason, the European Court of Human Rights and the European Commission of Human Rights did not provide protection as regards intellectual property issues. Namely, until the early 1990s, there were no complaints filed alleging violations of property rights. And when there were complaints filed alleging 
such violations, the Court and the European Commission summarily dismissed these complaints. The restrictive interpretation of Article 1 applied by the two tribunals resulted in an absence of searching scrutiny of national courts and administrative agencies. At the same time, it allowed Europe's intellectual property system to evolve largely unfettered by human rights concerns (Helfer, 2008: 2-3)

Today, this judicial reticence is not the case anymore. Namely, the European Court of Human Rights has already issued a couple of significant decisions as regards the protection of intellectual property rights before the Court, within which it concludes that patents, trademarks, copyrights, and other economic interests in intangible knowledge goods are protected by the European Convention's right of property. Moreover, the general principles established as regards reviewing alleged violations of Article 1 of Protocol No. 1 are also applied in case of reviewing alleged violations of intellectual property rights, whose protection arise from the protection of the right to property, provided by Article 1 of Protocol 1 of the Convention (Helfer, 2008: 3, 11)

In the 1990s, the European Commission has held that patents and copyrights fall within the scope of Article 1 Protocol 1 (Lenzing AG v. United Kingdom, Aral v. Turkey and Smith Kline \& French Lab. Ltd. v. Netherlands). However, the Court did not directly addressed the issue until 2005, when three significant judgements were issued in connection with the intellectual property protection before the European Court of Human Rights, whereby the Court applied Article 1 of Protocol 1 to intellectual property disputes: Dima v. Romania, Melnychuk v. Ukraine и Anheuser-Busch Inc. v. Portugal. The case Anheuser-Busch Inc. v. Portugal is the most well-known of these three cases. In that judgment, a Chamber of the ECtHR consisted of seven judges has concluded that "intellectual property as such incontestably enjoys the protection of Article 1 of Protocol 1." In 2006, the case was reargued before the Grand Chamber of the Court, consisted of seventeen judges. The Grand Chamber has unanimously confirmed the conclusion of the Chamber in its judgment issued in 2007, finding that Article 1 "is applicable to intellectual property as such." In other words, it confirmed that the right to property protects the financial interests of the intellectual property owners as regards their inventions and creations (Helfer, 2008: 12).

The judgment of the Grand Chamber of the Court, issued in 2007 in the case of Anheuser-Busch Inc. v. Portugal, is particularly striking also because the Court concluded that both registered trademarks and applications to register trademarks fall within the scope of the property rights clause of the ECHR. The analysis of this case suggests that the Court actually recognizes wider human rights implications on the regional innovation and creativity politics, as well as that its future decisions could have a significant impact on the intellectual property protection standards in Europe (Santos 2013: 11).

The only justification of the Court to reach the conclusion that intellectual property enjoys the protection of Article 1 of Protocol No. 1 is found in a brief quotation of the admissibility decision, adopted in 1990 by the European Commission, in the case of Smith Kline \& French Lab. Ltd. v. Netherlands. It was the first intellectual property decision issued by the European Commission, within which it is stated that "under Dutch law, the holder of a patent is referred to as the proprietor of a patent and that parents are deemed, subject to the provisions of the Patent Act, to be personal property which is transferable and assignable. The Commission finds that a patent accordingly falls within the scope of the term "possessions" in Article 1 of Protocol 1" (Helfer, 2008: 12-13).

In cases where Article 1 intersects with intellectual property subject matter and ownership rules, for example, where ownership is contested or where it is unclear whether an inventor or creator has satisfied the requirements for protection under domestic law. Literary and artistic works are protected from the moment of their creation or fixation. If the ownership and eligibility of these works is undisputed, the Court will simply rely to the national copyright or neighboring rights laws and conclude that Article 1 is applicable. However, this manner may not always give answers, especially when domestic law provides limited directions concerning a creator's proprietary interests (Helfer, 2008: 13-14). 
These complexities can be noticed in the admissibility decision from 2005 as regards the case of Dima v. Romania. This case is concerned with a design submitted to government-sponsored competition, which was ultimately chosen as an official state emblem. The focus of the dispute in the national courts was on the question of who ought to be recognized as the 'author' of the design: Dima, the original creator, or the Romanian Parliament, which had commissioned the design. The national court decided that the Parliament was to be deemed the 'author' of the design in such circumstances and therefore no fee was payable. Dima brought a complaint under the ECHR, claiming that this decision violated his rights under Article 1 Protocol 1. However, his claim was held to be inadmissible. The Court concluded that the national court has simply resolved a dispute about the interpretation of the scope of a property right in national law in a manner that was not arbitrary and, therefore, it was inappropriate for the Strasbourg Court to intervene. Moreover, the Court concluded that in cases where the existence or extent of copyright is uncertain, it is the task of the domestic courts to resolve any ambiguities. Only once those ambiguities have been resolved, the Court can determine the extent of the applicant's property right and whether the state had violated that right (Griffiths and McDonatgh, 2013: 87-88).

The eligibility of industrial property for protection is determined by a registration procedure. A different set of ambiguities arises with respect to the Court's treatment of industrial property (Helfer, 2008: 13, $18)$.

The case of Anheuser-Busch Inc. v Portugal considered a dispute between the American company, Anheuser-Busch Inc., and the Czech brewer, Budejovicky Budvar. Anheuser-Busch claimed that the Portuguese court had violated Article 1 Protocol 1, in upholding the national authority's refusal to register its application for registration of the trade mark, 'Budweiser'. The decision to refuse the application had been based on the fact that Budejovicky Budvar owned a registered 'protected geographical indication' for 'Budweiser Bier', a registration which the national decision maker held to take precedence over Anheuser-Busch's trade mark application by virtue of a complex effect of an international treaty on domestic law. The Court, in its Grand Chamber judgment from 2007, held that the mere application for trade mark application could qualify as a 'possession' for the purposes of Article 1 Protocol 1, and, therefore, that Anheuser-Busch's claim fell within the scope of the protected right. The application constituted a possession because an applicant had a legitimate expectation that it would be handled fairly by national authorities and because there was evidence that such applications were tradeable. However, the Court concluded that the national court had simply interpreted an uncertain aspect in national intellectual property law and it was not the Court's role to review such a determination of the competing claims to entitlement to a mark, stating that: “...The Court reiterates that its jurisdiction to verify that domestic law has been correctly interpreted and applied is limited and that it is not its function to take the place of the national courts, its role being rather to ensure that the decisions of those courts are not flawed by arbitrariness or otherwise manifestly unreasonable" (Griffiths and McDonatgh, 2013: 87).

Similarly, in Melnychuck, the Court held that providing intellectual property owners with a judicial forum to adjudicate domestic infringement claims did not automatically engage the state'sresponsibility" under Article 1. Only "in exceptional circumstances" could the state "be held responsible for losses caused by arbitrary determinations" (Helfer, 2008: 37).

However, some cases also contain a broader vision for the Court's adjudication of intellectual property disputes. In the Grand Chamber's Anheuser-Busch ruling, the Court's interpretation of Article 1 is that states are required to provide statutory, administrative, and judicial mechanisms that allow intellectual property owners to prevent third parties from infringing their protected works. Namely, the Court concluded that public authorities have positive obligations to take affirmative steps in order to ensure that rights holders can effectively exercise their rights (Helfer 2008: 40). 


\section{CONCLUSION}

This paper provides an analysis of the genesis of the right to property, as well as its development and treatment starting from Magna Carta to the European Convention on Human Rights. It can be concluded that the Great Charter of 1215 provided the foundation for property rights protection by establishing the clear principle that a person's property could not be seized by the King, "except by the lawful judgment of his peers or by the law of the land". Both Sir Edward Coke and Sir William Blackstone interpreted Magna Carta as prohibiting the adoption of arbitrary laws and guaranteeing that no freeman shall be deprived of his life, liberty, or property.

The revolutionary ideas on property were further developed by John Lock, who cultivated property rights as part of the human rights framework by stating and elaborating that "every man has a property in his own person...the labor of his body... are property his". Moreover, he claimed that property serves as guarantor of liberty since it is "the protection of consent...not merely or chiefly what supplies men's needs". Lock's arguments on property were later incorporated in the US Constitution (1789) and the Declaration of the Rights of Man and of the Citizen (1791).

Consequently, it could be argued that property rights are the foundation of all human rights, particularly having in mind that the very basis of natural rights theory is that people own their own bodies and should be free to exercise their capabilities to pursue their lives, opportunities and enterprise unless they do harm to others.

Yet, despite property rights providing the foundation for human rights, the subject has always been controversial in their modern development, particularly through international treaties, such as the Universal Declaration of Human Rights and the European Convention on Human Rights. Many legal scholars and philosophers recognize the importance of protecting property as a fundamental right. Although they differ on the justification for and scope of that protection, it is clear that there is a general consensus that protection of private property is essential to preserving the rule of law.

The paper also provides a comparison between the Magna Carta and the European Convention of Human Rights and concludes that the ECHR can be viewed as a modern equivalent of Magna Carta.

Furthermore, the paper provides an analysis of the jurisprudence and the role and approach of the European Court of Human Rights regarding the protection of the right to property. It can been concluded that not only the Court has created a very complex jurisprudence as a result of the interpretation of the right to property, but it has also extended the protection of property to intellectual property as well. The latter has been done through the adoption of decisions that interpret the right to property, in relation to intellectual property protection claims.

Based on the analysis of the jurisprudence of the Court regarding the intellectual property rights protection, it can be concluded that in most cases the Court would treat intellectual property no differently than any other type of real, personal, or intangible property protected by Article 1 . The Court does not consider the public-good qualities of intellectual property rights, nor the social and cultural policies which justify the state's protection of those rights. Namely, it finds violation only with arbitrary government conduct, such as ultra vires actions, failure to follow previously established rules and procedures, or laws that contravene the rule of law principles. The Court's scrutiny of national decision makers is minimal and it allows government's discretion to shape their domestic innovation and creativity policies as they see appropriate, provided that they respect the previously established rules embodying those policies.

However, some cases contain a broader vision as regards the Court's adjudication in intellectual property protection disputes, in the sense that the states should provide statutory, administrative, and judicial mechanisms that ensure intellectual property owners can effectively exercise their rights. This is likely to generate a new wave of complaints regarding the adequacy of domestic enforcement 
procedures. These complaints will require the Court to determine more precisely which mechanisms states must provide to enable rights holders to prevent and punish violations by third parties. When determining the implicit positive obligations of Article 1, the Court may rely on the domestic enforcement provisions of the Agreement on Trade-Related Aspects of Intellectual Property Rights (TRIPS), administered by the World Trade Organization.

It is very likely that this approach would lead to problems and ambiguities due to two reasons. The first reason is the different judicial access rules of the WTO and the Court. Namely, within the WTO only states can file complaints alleging violations of TRIPS. The second reason relates to the dissimilar remedies that the WTO and the Court award. Namely, the Court's remedies are more expansive in the sense that they include recommendations to reopen closed court proceedings, revise domestic statutes, and award restitution in kind.

The paper concludes that the targeting of the arbitrary government conduct, in order to protect the rule of law principle, is the strongest justification for the European Court of Human Rights to find in favor of intellectual property owners. This minimalist approach serves the Convention's core values of promoting predictability, certainty, and respect of the rule of law, without excessive constraining of the discretion of national legislators and judges to shape domestic intellectual property rules according to local circumstances.

Overall, it can be concluded that the right to property has impressively evolved in the last 8 centuries, starting from Magna Carta as a simple principle that a person's property cannot be seized by the King to being recognized and protected as a fundamental human right within the European Convention on Human Rights.

\section{BIBLOGRAPHY}

\section{BOOKS AND PAPERS:}

Bates, Ed, The Evolution of the European Convention on Human Rights: From Its Inception to the Creation of a Permanent Court of Human Rights, OUP Oxford, 2010

Chapman, Audrey R., A Human Rights Perspective on Intellectual Property, Scientific Progress, and Access to the Benefits of Science, WIPO Publication No.762(I), Geneva, 1999

Coban, Ali Riza, Protection of Property Rights within the European Convention of Human Rights, Ashgate Publishing, 2004

Cullet, Philippe, Human Rights and Intellectual Property Protection in the TRIPS Era, The John Hopkins University Press, Human Rights Quarterly, Volume 29, No.2, 2007

Griffits, Johnatan and McDough, Luke, Constructing European Intellectual Property, Achievements and New Perspectives, Edvard Elgar Publishing Limited, Cheltenham \& Edvard Elgar Publishing Inc, Northampton, 2013

Grgic, Aida, Mataga, Zvonimir, Longar, Matija and Vilfan, Ana, The Right to Property under the European Convention on Human Rights A Guide to the Implementation of the European Convention on Human Rights and Its Protocols, Council of Europe, 2007

Helfer, Laurence R., The New Innovation Frontier? Intellectual Property and the European Court of Human Rights, Harvard International Law Journal, Volume 49, 2008 
O'Neill, Johnathan, Property Rights and the American Founding: An Overview, Supreme Court Historical Society, Volume 38, Issue 3, 2013

Rathbone, Mark, The Human Rights Act: a Magna Carta for the Twenty-First Century?, Political Studies Association, 2014

Renucci, Jean-François, Introduction to the European Convention on Human Rights The rights guaranteed and the protection mechanism, Council of Europe, 2005

Santos, Ana Eduarda, Reballancing Intellectual Property in the Information Society: The Human Rights Approach, Duke Law School, 2013

Schmidtz, David, The Institution of Property, Social Philosophy and Policy, No.11, 1994

Siegan, Bernard H., Property Rights: From Magna Carta to the Fourteenth Amendment, Transaction Publishers, 2001

Спировски, Игор, Јуриспруденщијата на Европскиот суд за човекови права (збирка на пресуди), 2-ри Август С, Штип, 2007

Welkowitz, David S., Privatizing Human Rights? Creating Intellectual Property Rights from Human Rights Principles, New York University, Volume 43, No.3, Article 3, 2013

Wilson, Tim, Property Rights are Human Rights, IPA Review, Volume 67, No.I, Article 2, 2015

\section{LEGAL DOCUMENTS:}

Magna Carta, Runnymede, 15.6.1215

Convention for the Protection of Human Rights and Fundamental Freedoms as amended by Protocols No.11 and No.14, Rome, 4.11.1950

Cases of the European Commission of Human Rights and the European Court of Human Rights:

Akkus v. Turkey, July 9, 1997, Reports 1997-IV

Anheuser-Busch Inc. v. Portugal, App.No.73049/01, 44 Eur. H.R. Rep. 42 [846], 855-56 (Chamber 2007) (judgement of Oct. 11, 2005)

Anheuser-Busch Inc. v. Portugal, App.No.73049/01, 45 Eur. H.R. Rep. 36 [830], (Grand Chamber 2007)

Aral v. Turkey, App.No.24563/94 (1998) (admissibility decision)

Dima v. Romania, App.No.58472/00, para 87 (2005) (admissibility decision)

Draon v. France, App.No.1513/13, 42 Eur.H.R. Rep.40 [807], 832-33 (2006) (judgement of Oct.6, 2005)

Fedorenko v. Ukraine, App.No.25921/02, 29 (2006)

Forrer-Niedenthal v. Germany, February 20, 2003, App.No. 46316/99

Jahn v. Germany, App.No.46720/99, 42 Eur.H.R.Rep.49 [1085], 1105 (Grand Chamber 2006) (judgement of June 30, 2005)

Lenzing AG v. United Kingdom, App.No.38817/97, 94-A Eur. Comm’ H.R. Dec.\&Rep.136 (1998) 
Melnychuk v. Ukraine, App.No.28743, para.8 (2005) (admissibility decision)

Motais de Narbonne v. France, July 2, 2002, App.No. 48161/99

Smith Kline \& French Lab. Ltd v. Netherlands, App.No.12633/87, 66 Eur. Comm’ H.R. Dec.\&Rep. 70, 79 (1990) (admissibility decision)

Sporrong and Lonnroth v. Sweden, September 23, 1982, A 52, § 63

Tre Traktorer AB v. Sweden, July 7, 1989, A 159, § 53

Van Marle and Others v. the Netherlands, June 26, 1986, A 101

Wiggins v. the United Kingdom, EC, February 8, 1978, DR 13/40

Zhigalev v. Russia, App.No.54891/00, 131 (2006)

Zubani v. Italy, August 7,1996, Reports 1996-IV 